\title{
A Bayesian analysis of the parasitic ecology in Jenynsia multidentata (Pisces: Anablepidae)
}

\author{
Martin M. Montes \& Sergio R. Martorelli
}

\begin{abstract}
Jenynsia multidentata Jenyns, 1842 (one-sided livebearers) are euryhaline viviparous fish of small size, used in the laboratory experiment, important as resource for biological control of mosquito's larva and a key species to recover eutrophic lakes. Works have been published dealing with parasite biodiversity of this host, but little has been studied about the parasite community ecology. From early 2009 to ends of 2010 specimens of $J$. multidentata were collected from two places, the Salado Relief Channel (S.R.C.) on Samborombón Bay and the Sauce Chico River near to the city of Bahia Blanca (B.B.). All fish were sexed, measured and grouped into sizes/age classes. The fishes from both sites harbored 16 parasitic species: nine digenean, one monogenean, one metacestode, one acanthocephalan, two nematode and two copepods. Lecithaster confusus Odhner, 1905, the metacercariae Hemiuridae gen. sp. indet., metacercariae Thylodelphys sp. (inside the eye), Glossocercus sp. nematode L4 (intestine) and Ergasilus sieboldii Nordmann, 1832 are new records for the host. The high number of larval stages made of this fish a link between micro and macroecosystems. The size 2 had the higher biodiversity in both sites, which could be the most suitable age to store the maximal number of parasite of the environment and have a more equitability in their distribution on the host. In B.B. some parasites had higher prevalence and mean abun dance due to the small size of the waterbody compared with the S.R.C. Despite that, in S.R.C. exist a higher specific richness and biodiversity due the daily flow of saline and freshwater and proximity of the sample site to the mouth of the channel in the bay. This is the first approximation to an analysis of the parasitic ecology on this host.
\end{abstract}

KEYWORDS. Diversity, Samborombon Bay, Bahia Blanca, Salado River Relief Channel, Low Sauce River.

RESUMEN. Un análisis bayesiano de la ecologia parasitaria em Jenynsia multidentata (Pisces: Anablepidae). Jenynsia multidentata Jenyns, 1842 (madrecitas) son peces viviparous, eurihalinos de pequeño tamaño usados en experimientos de laboratorio, como un recurso importante para el control biológico de larvas de mosquito y una especie clave para recuperar lagos eutrofizados. Han sido publicados varios trabajos acerca de la biodiversidad parasitaria de este pez pero poco es conocido acerca de la ecologia de la comunidad parasitaria de este hospedador. pero poco se conoce acerca de su ecología parasitaria. Durante los meses de primavera y verano en el 2009 y 2010, especímenes de J. multidentata se colectaron del Canal Colector del Salado (S.R.C.) en la Bahía de Samborombón y del Rio Sauce Chico cercano a la ciudad de Bahía Blanca (B.B.), fueron sexados, medidos y agrupados en clases según su tamaño/edad. Los peces de los dos sitios albergaron 16 especies de parásitos: nueve digeneos, un monogeneo, un cestodo, un acantocéfalo, dos nematodos y dos copépodos. Lecithaster confusus Odhner, 1905, la metacercaria Hemiuridae gen. sp. indet., metacercaria Thylodelphys sp. (en el ojo), Glossocercus sp. nematode L4 (intestino) y de Ergasilus sieboldii Nordmann, 1832 son nuevas citas para el hospedador. El gran número de estadios larvales hacen de este pez un nexo entre micro y macroecosistemas. La talla 2 tuvo una mayor biodiversidad en ambos sitios, la cual puede ser la edad más apropiada para recolectar el máximo número de parásitos del ambiente y tener una distribución dentro del hospedador de mayor equitabilidad. En B.B. algunos parasitos tuvieron mayor prevalencia y abundancia media debido al menor tamaño del cuerpo de agua comparado con S.R.C. A pesar de esto, en S.R.C. existe una mayor riqueza específica y biodiversidad debido al flujo diario de agua dulce y salina y a la proximidad del sitio de muestreo a la desembocadura del canal en la Bahía. El gran número de parásitos en los machos puede deberse a un cambio en el uso de la energía que se focaliza en la reproducción. Esta es la primera aproximación a un análisis de la ecología parasitaria de este hospedador y, como resultado, podemos ver algún tipo de influencia del mismo que no debe ser ignorado y debería ser estudiado en el futuro considerando cada parasito como la interrelación entre ellos y el hospedador.

PALABRAS-CLAVE. Diversidad, Bahía de Samborombon, Bahía Blanca, Canal Colector del Río Salado, Río Sauce Chico.

Jenynsia multidentata Jenyns, 1842 is a eurihaline fish of small size and viviparous (SICCARDI, 1940; MENNI et al., 1996; Beтiтo, 2006). These fishes feed of micro and meso animals (RINGUELET et al., 1967; RiNGUELET, 1975; EsCALANTE, 1987) and represent a link between zooplankton and birds or bigger fishes. The great power of adaptation, reproduction and feed habits of the viviparous fish $J$. multidentata (known as "one-sided livebearers") makes this species an useful resource as biological control of mosquitoes larvae (MARTI et al., 2006), experimentation fish in the laboratory (for example, VALDES et al., 2016) and a key species to recover eutrophic lakes (IgLESIAS et al., 2008).

The role played by this fish in the food chain is important in the lifecycle of the parasites because a large number of larvae are hosted. In Argentina parasites hosted by $J$. multidentata was studied mainly by OsTROWSKI DE NuÑEz $(1974,1976,1992,1993,1998,2001)$ and SzIDAT (1969). This fish also host the acanthocephalan Wolffughelia 
matercula Mañé-Garzón \& Dei-Cas, 1974 found in Argentina by LunASCHI \& Drago (1995). Moreno et al. (1986) report Lernaea cyprinacea (Linnaeus, 1758) parasitizing one-sided livebearers. Only ROMERo (2005) in her grade-thesis made an approach to the ecological research of the community ecology of this important fish.

The main objective of this manuscript is to compare the parasitological fauna of J. multidentata with Bayesian statistics in two estuarine environments from Argentina.

\section{MATERIALS AND METHODS}

Among the months of spring and summer of 2009 and 2010, 377 specimens of $J$. multidentata (one-sided livebearers) were collected from the Salado Relief Channel (S.R.C) on Samborombón Bay (35 $\left.57^{\prime} \mathrm{S} ; 5^{\circ} 25^{\prime} \mathrm{W}\right)$ and the Sauce Chico River (B.B.) (Fig. 1), close to the locality of Coronel Cerri in the Bahia Blanca estuary ( $\left.39^{\circ} 11^{\prime} \mathrm{S} ; 62^{\circ} 03^{\prime} \mathrm{W}\right)$. The S.R.C. located in the north of the Samborombón Bay is a wide channel connected with the Salado river near its mouth in the Bay.

The sample site is near the mouth over the Rio de $\mathrm{La}$ Plata river and is influenced by the winds and the marine tide. In this site it is possible to capture marine organisms like jellyfish and marine fish, or typical freshwater animals like catfish. The Sauce Chico River is a slender and shallow river which flows into the Bahia Blanca estuary. The sample site is far from the mouth. In this river was sampled characid fishes, characteristic of freshwaters from the continent (the salinity was not measured).

The specimens of $J$. multidentata were transported to the lab in bags with water of the sampling site and added oxygen. In the laboratory, they were maintained in aquariums until the parasitological examination. The onesided livebearers were euthanized with the lower possible pain, measured in their standard length (SL) and total length (TL), weighed and sexed. Measurements are expressed in centimeters and grams. The sizes were established according to LOPEZ CAZORLA et al. (2003), and represents: size 1 (S1) a maximum TL of $4.5 \mathrm{~cm}$ (correspond to the age $0-1$ ), size 2 (S2) between $4.5-6 \mathrm{~cm}$ (to the age 1-2) and the size 3 (S3), more than $6 \mathrm{~cm}$. The number of specimens, by sex, size, site and year of collection are provided in Tab. I.

Fish were examined for parasites under stereoscopic binocular microscope. The parasites were studied alive. The digeneans, cestods, and monogeneans were heat killed without pressure between slices and then preserved in $10 \%$ formaline. Acantocephalans were put in distillated water and leaved in freezer until the proboscis was everted and then preserved in $70 \%$ alcohol. Nematodes were relaxed in hot $70 \%$ alcohol. Copepods were fixed in $10 \%$ formaline. The parasites were stained and mounting according to PRITCHARD \& KRUSE (1982). The nematode, acanthocephalans and copepods were cleared with lactic acid and observed under light microscopy.

The parasitological indexes: prevalence $(\mathrm{P})$, intensity (I) and mean abundance (MA) were calculated with the software WinBUGS and the terminology used according to Bush et al. (1997). According to MagurRan (1988) were calculated the Berger Parker dominance index, the number of parasitic species (S), the number of parasites $(\mathrm{N})$, the Shannon-Wiener diversity index (Shannon) and the Pielou evenness index (Pielou). The Shannon-Wiener diversity index and Pielou evenness index were calculated in WinBUGS according to the codes provided by GoLLICHER et al. (2006), the $\mathrm{S}$ and $\mathrm{N}$ were calculated with the same program.

The software WinBUGS generates 100,000 samples from the posterior distributions for each analysis after discarding the initial 10,000 samples as a "burn in". The mean and the $2.5^{\text {th }}$ and $97.5^{\text {th }}$ percentiles of the distribution of each parameter were calculated. This interval was used to represent a 95\% Bayesian credible interval. The first year sampled was used as "prior" to the second year. A significance level $(\alpha)$ of $5 \%$ or less was considered significant $(p<=0.05)$.

The vouchers specimens were deposited in the Helminthological Collection of Museo de La Plata, under the numbers MLP 6773 Lecithaster confusus Odhner, 1905; MLP 6774 metacercaria Ascocotyle (Phagicola) diminuta (Stunkard \& Haviland, 1924); MLP 6775 metacercaria Ascocotyle (Phagicola) angeloi Travassos, 1928; MLP 6776 metacercaria Ascocotyle (Phagicola) felippei Travassos, 1929; MLP 6777 metacercaria Ascocotyle (Phagicola) hadra Ostrowski de Núñez, 1992; MLP 6778 metacercaria Pygidiopsis macrostomum Travassos, 1928, MLP 6779 metacercaria Echinostomatidae gen. sp., MLP 6780 metacercaria Hemiuridae gen. sp., MLP 6781 metacercaria Thylodelphys sp.; MLP 6782 Gyrodactylus sp.; MLP 6783 Glossocercus sp.; MLP 6784 Wolffhugelia. matercula; MLP 6785 Spirurida larvae nematode (L4) L4 Orden Spirurida; MLP 6786 Contracaecum sp.; MLP-Cr 26943 Ergasilus sieboldii Nordmann, 1832; ML-Cr 26944 Lernaea cyprinacea. The host voucher was deposited in the ichthyologic collection of the Museo de la Plata under the number MLP 11228.

\section{RESULTS}

The Figure 2 shows the comparison between T.L., S.L. and weight of males and females of both sites without separation in sizes. In S.R.C. the males and females are bigger than in B.B. In S.R.C. the males are significantly smaller than the females. In B.B., males and females are quite similar in the length and weight. The next comparison of the females and males were made according to their sizes (ages).

Fish studied from S.R.C. and B.B. harbored nine digeneans, one monogenean, one cestode, one acanthocephalan, two nematodes and two copepods, in total 16 parasitic species. The P., M.A. and I. of the parasites according to the host sex, sizes and site of collection are provided in the Tab. II. Lecithaster confusus, Met. Hemiuridae and E. sieboldii were found only in S.R.C. The P. in S1, $\mathrm{S} 3$, and males of the parasite $A$. (P.) diminuta were higher in B.B. compared with S.R.C. The P., M.A. and I. of met. $A$. (P.) angeloi in the $\mathrm{S} 1$ (males and females) were higher 


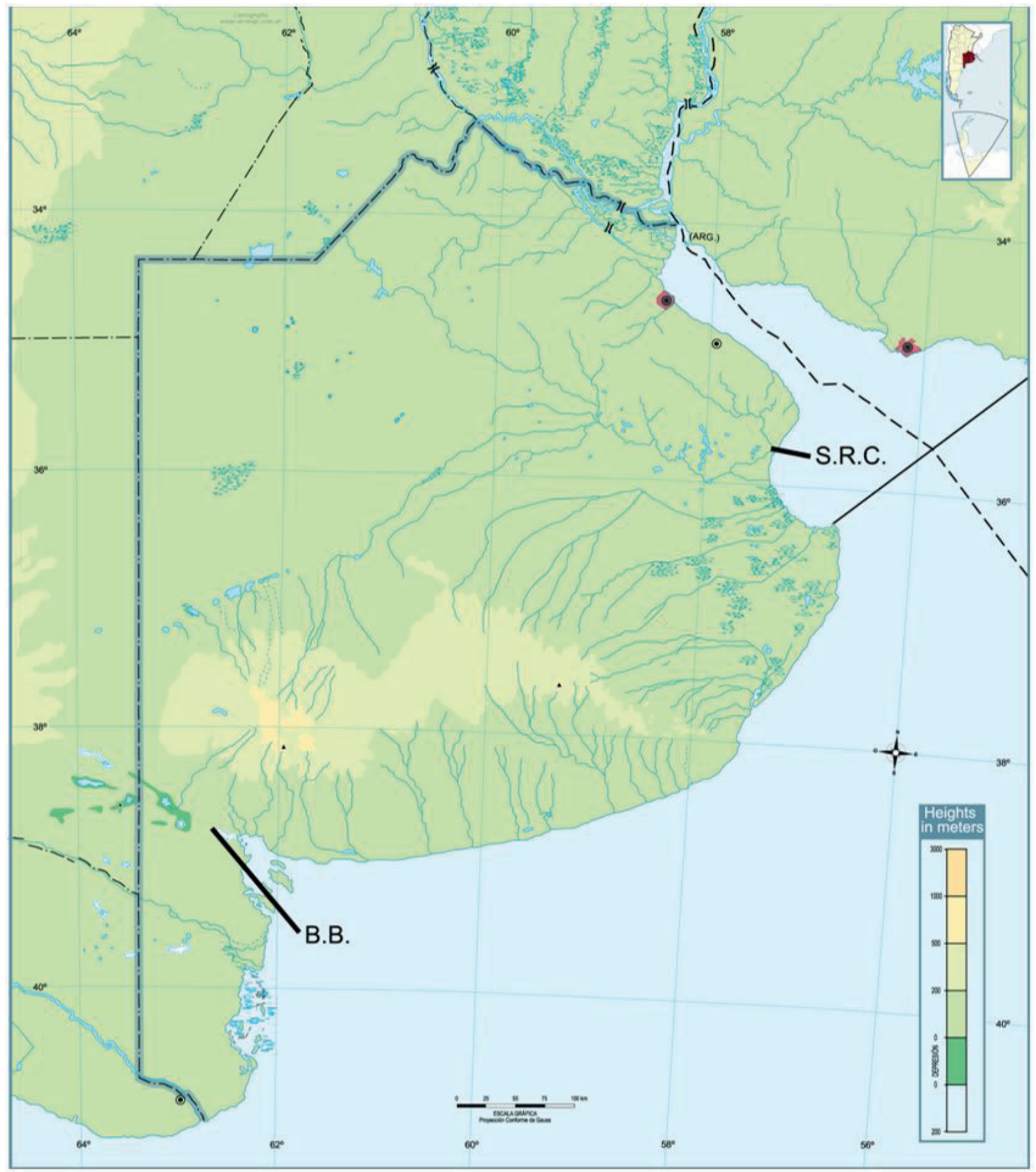

Fig. 1. Map of the sample sites, Salado Relief Channel (S.R.C.) in Samborombon Bay and the Sauce Chico River in Bahia Blanca estuary (B.B.), Argentina.

in B.B. The M.A. of the met. A. (P.) felippei infecting S1, was higher in B.B.; infecting S2 was higher in S.R.C.; the I. was higher in the S3 from B.B., and the P., M.A. and I. in males were higher in B.B. The P., M.A., and I. of the met. A. (P.) hadra were higher in the males of B.B. The P., M.A., and I of the met. P. macrostomum in $\mathrm{S} 1$ were higher in B.B.; the P., M.A., and I. infecting S3 were higher in
S.R.C.; the males of the boty sites had similar P., but the M.A. and I. were higher in B.B. The P., M.A., and I of the met. Echinostomatidae infecting $\mathrm{S} 1$ and the males were higher in B.B.; the P., M.A., and I infecting S3 were higher in S.R.C. The P., M.A., and I. of the cestode Glossocercus sp. infecting S3 were higher in S.R.C. The P., M.A. and I. of the acanthocephalan $W$. matercula were higher in S.R.C. 
Tab. I. Number of Jenynsia multidentata Jenyns, 1842 according to year, sample site, sex and size [B. B., low Sauce River of Bahia Blanca; F., females; M., males; S.R.C., Salado River Channel; S1, size 1 (T.L. $<45$ mm); S2, size 2 (T.L. = 45-60 mm); S3, size 3 (T.L. > 60 mm)].

\begin{tabular}{|c|c|c|c|c|c|}
\hline & & & 2009 & 2010 & Total \\
\hline \multirow{5}{*}{ S.R.C. } & & $\mathrm{S} 1$ & 48 & 14 & 62 \\
\hline & F. & $\mathrm{S} 2$ & 2 & 10 & 12 \\
\hline & & $\mathrm{S} 3$ & 0 & 7 & 7 \\
\hline & M. & $\mathrm{S} 1$ & 50 & 48 & 98 \\
\hline & Total & & 100 & 79 & 179 \\
\hline \multirow{5}{*}{ B.B. } & & $\mathrm{S} 1$ & 29 & 52 & 81 \\
\hline & F. & $\mathrm{S} 2$ & 14 & 6 & 20 \\
\hline & & $\mathrm{S} 3$ & 4 & 0 & 4 \\
\hline & M. & $\mathrm{S} 1$ & 52 & 41 & 93 \\
\hline & Total & & 99 & 99 & 198 \\
\hline TOTAL & & & 199 & 178 & 377 \\
\hline
\end{tabular}

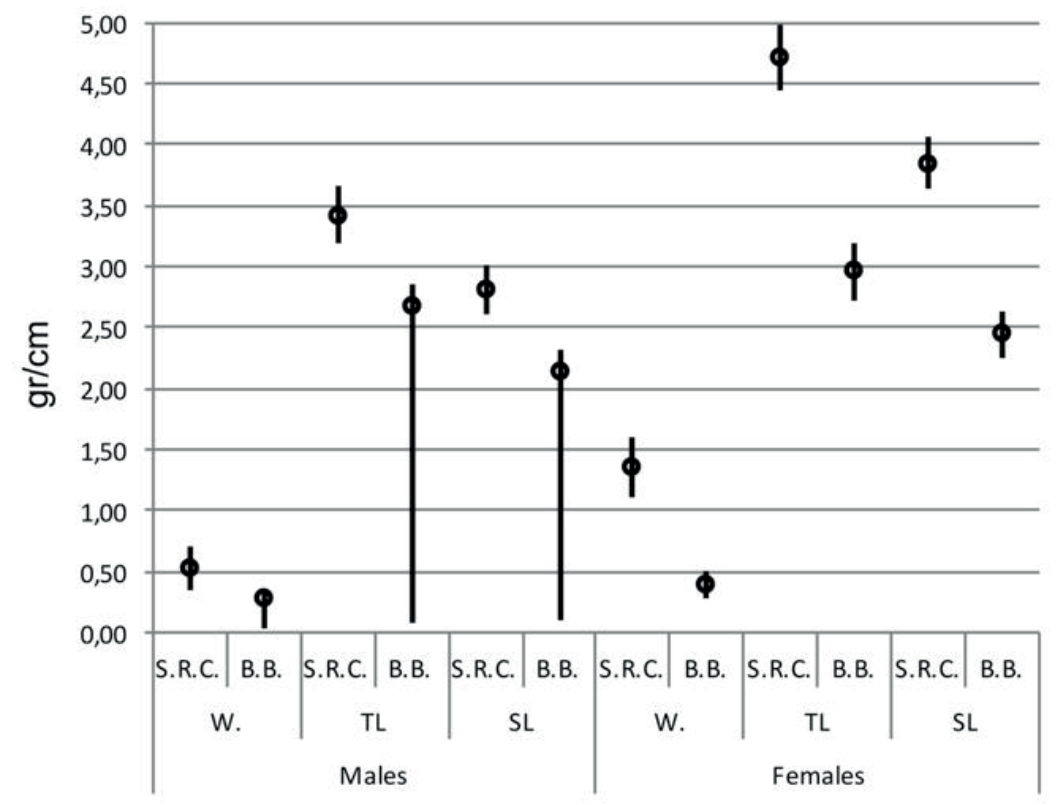

Fig. 2. Mean and the $95 \%$ credibility range of Weight (W.) in grams (gr), total and standard length (TL and SL) in centimeters of Jenynsia multidentata Jenyns, 1842 in Salado River Channel (S.R.C.) and Low Sauce River of Bahia Blanca (B.B.), Argentina.

The P., M.A., and I of the nematode Contracaecum sp. in $\mathrm{S} 1, \mathrm{~S} 2$ and $\mathrm{S} 3$ were higher in B.B.

The comparison between the female body sizes of $J$. multidentata in S.R.C. showed higher I. in S2 and S3 of the parasite: $A$. (P.) diminuta, $A$. (P.) felippei, met. Echinostomatidae and $E$. sieboldii; the M.A. of the met. Echinostomatidae and Nematoda L4 was higher in the S2 and S3.

The comparison between the female body sizes of J. multidentata in B.B. showed a higher P., M.A., and I. of the $A$. (P.) felippei in $\mathrm{S} 1$ and $\mathrm{S} 3$ against $\mathrm{S} 2$. The M.A. and I. of the Pygidiopsis macrostomum were higher in $\mathrm{S} 1$; the P. of the met. Echinostomatidae was higher in S1; the P. and M.A. of the nematode L4 were higher in S3; the P. of the nematode Contracaecum sp. was higher in $\mathrm{S} 3$ compared with $\mathrm{S} 1$, but there was not differences when the comparison was between $\mathrm{S} 2$ and $\mathrm{S} 3$.
When the comparison was between males and females of S1 in S.R.C., we found: the M.A. of the met. Echinostomatidae was higher in the females; the P., M.A., and I. of the met. Hemiuridae were higher in the males.

The comparison between males and females of $\mathrm{S} 1$ in B.B. showed higher P. of $A$. (P.) hadra in the females of S1; the P. and M.A. of the met. P. macrostomum were higher in the females of S1; the M.A. of the nematode L4 was higher in males of S1; the P. and M.A. of the nematode Contracaecum sp. were higher in females of S1.

In the Tab. III could be observed the Dominance Index of Berger Parker calculated for the most abundant species according to the microhabitat in the host: intestine, musculature, branchial arch, mesentery/coelom, skin and eyes. The Dominance Index of Berger Parker in the gills were higher value for the met. Echinostomatidae and, then, the met. A. (P.) diminuta; in the aortic bulb was the met. 
Tab. II. Microhabitat of parasite infection on the Jenynsia multidentata Jenyns. 1842. Prevalence, mean abundance and mean intensity infection of the parasite species according sample site, host sex and size. The mean of prevalence, abundance and intensity are followed by the credibility range in parenthesis [A.B., aortic bulb; B.B., low Sauce River of Bahia Blanca; E., eye; F., females; G., gills; I., intensity; In., intestine; M., males; M.A., mean abundance; Met., metacercariae; Mu., musculature; My., Mesentery; P., Prevalence; S., skin; S.I., site of infection; S.R.C., Salado River Channel; T.L., total length; S1, size 1 (T.L. $45 \mathrm{~mm}$ ); S2, size 2(T.L. $=45-60 \mathrm{~mm}$ ); S3, size 3 (T.L. $>60 \mathrm{~mm}$ )].

\section{DIGENEA}

Met. Ascocotyle (Phagicola) diminuta (Stunkard \& Haviland, 1924)

Lecithaster confusus Odhner, 1905

$$
\text { 1924) }
$$

Met. Ascocotyle (Phagicola) angeloi

Travassos, 1928

Met. Ascocotyle (Phagicola) felippei Travassos, 1929

Met. Ascocotyle (Phagicola) hadra Ostrowski de Núñez, 1992

Met. Pygidiopsis macrostomum Travassos, 1928

S.I. P.

\section{S1}

S.R.C. F.

M.

M.

B.B.

$\begin{array}{ll} & \text { S3 } \\ \text { M. } & \text { S1 } \\ & \text { S1 } \\ \text { F. } & \text { S2 }\end{array}$

S.R.C. F.

$\begin{array}{ll}\text { M. } & \text { S1 } \\ & \text { S1 } \\ \text { F. } & \text { S2 }\end{array}$

B.B.

.

$\begin{array}{ll}\text { M. } & \text { S1 } \\ & \text { S1 }\end{array}$

F. $\quad$ S2

M. S1

B.B

F. $\quad \mathrm{S} 2$

S3

$\begin{array}{lll} & & \text { S1 } \\ \text { S.R.C. } & \text { F. } & \text { S2 } \\ & & \text { S3 }\end{array}$

$\begin{array}{ll}\text { M. } & \text { S1 } \\ & \text { S1 }\end{array}$

B.B. F. $\quad$ S2

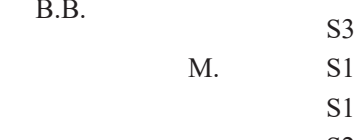

S.R.C. F. S2

F. $\mathrm{S} 3$

M. $\quad \mathrm{S} 1$

$\mathrm{S} 1$

$\begin{array}{lll}\text { B.B. } & \text { F. } & \text { S2 } \\ & & \text { S3 } \\ & \text { M. } & \text { S1 } \\ & & \text { S1 } \\ & \text { F. } & \text { S2 }\end{array}$

S.R.C. F. $\quad$ S2

$\begin{array}{lll} & \text { M. } & \text { S1 } \\ & & \text { S1 } \\ \text { B.B. } & \text { F. } & \text { S2 } \\ & & \text { S3 } \\ & \text { M. } & \text { S1 }\end{array}$

In.

$$
\begin{gathered}
19(3-37) \\
17(0.7-37) \\
- \\
3.4(0.5-10.9) \\
- \\
- \\
- \\
-
\end{gathered}
$$

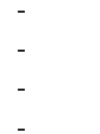

16 (7.30-24.60)

$21(3.20-42.10)$

$22(1.10-47.60)$

$14(7.60-20.90)$

G.

58 (47.80-68.70)

$59(39-78.70)$

$83(48-100)$

$61(51.40-71)$

$3(0.40-8.50)$

Mu.

3 (0.60-7.10)

38 (27.90-48.50)

$40(30.30-49.80)$

11 (3.90-18.60)

$17(0.70-36.80)$

33 (2.60-67)

$1.70(0.20-5.50)$

A.B.

$18(8.60-28.40)$

$3(0.40-7.90)$

$22(1.10-47.60)$

27 (18.70-36.40)

14 (6.10-22.60)

$29(7.50-51.40)$

44 (14.90-74.60)

8 (3.2-13.40)

My.

$30(21-33.90)$

18 (4.10-34)

67 (33-97)

44 (34.4-54.2)

3.9 (11-18.6)

$36(12.7-59.9)$

$56(25.4-85.1)$

$12(6-18.4)$

My.

75 (63-85.6)

$25(1.3-52.7)$

$26(17.7-35.2)$

$\begin{array}{cc}0.14(0.11-0.35) & 1 \\ 0.12(0.1-0.34) & 1 \\ - & - \\ 0.02(0.01-0.06) & 1 \\ - & - \\ - & - \\ - & - \\ - & -\end{array}$

$0.2(0.02-0.38)$

$0.69(0-2.70)$

$2.14(0-8)$

$0.11(0-0.20)$

$0.78(0.47-1.08)$

$2.03(0.52-3.55)$

$8.5(0-18.44)$

$1.18(0.77-2)$

$0.02(0-0.05)$

-
-
$0.02(0-0.05)$
$0.42(0.24-0.60)$

-
-
$0.02(0-0.05)$
$0.42(0.24-0.60)$

$1.55(1-3)$

$3.82(3.77-3.88)$

15 (14.92-15.08)

1.37 (1-2.46)

$2.14(1.56-2.71)$

$3.52(1-11.88)$

8.5 (1-18.44)

2.43 (1.78-3.09)

$0.51(0.29-0.73)$

$0.02(0.01-0.02)$

$0.4(0-1)$

$0.57(0-2)$

$<<0$

$0.29(0.07-0.52)$

$$
<<0
$$

$5(0-10)$

$0.31(0.14-0.49)$

$0.13(0.04-0.21)$

$0.3(0-0.80)$

$1.14(0-3.08)$

$0.05(0-0.11)$

$0.44(0.14-0.73)$

$0.2(0-0.48)$

$1.25(0-4)$

$0.74(0.51-0.98)$

$0.2(0.02-0.37)$

$0.88(0-2.09)$

$2.57(0-7.49)$

$0.16(0.1-0.35)$

$5.42(3.46-7.38)$

$0.17(0-0.68)$

$0.02(0-0.06)$ 
Tab. II. Cont.

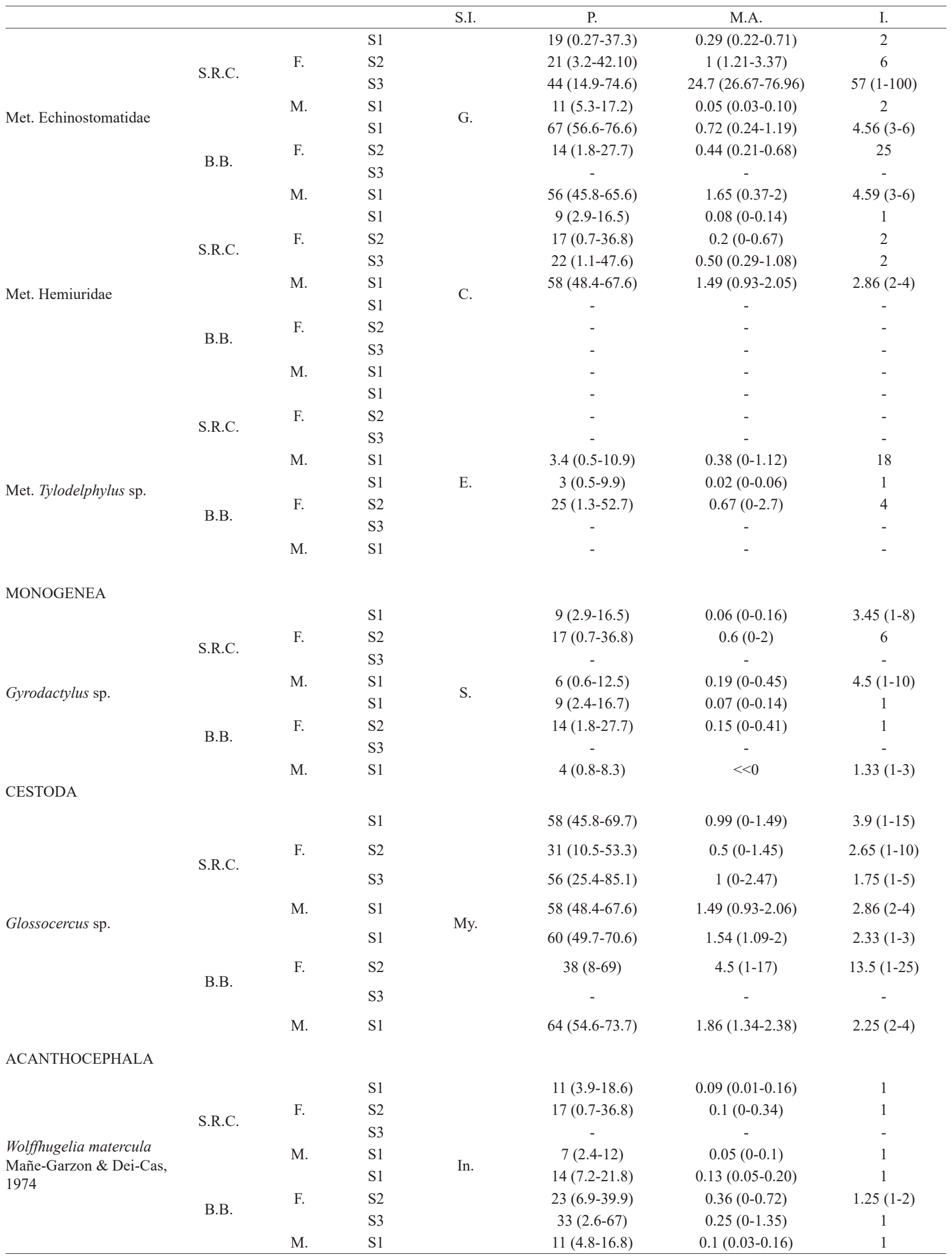


Tab. II. Cont

\begin{tabular}{|c|c|c|c|c|c|c|c|}
\hline & & & & S.I. & $\mathrm{P}$. & M.A. & I. \\
\hline \multicolumn{8}{|l|}{ NEMATODA } \\
\hline \multirow{8}{*}{ Larvae 4 gen. sp. indet. } & \multirow{5}{*}{ S.R.C. } & \multirow{3}{*}{ F. } & S1 & \multirow{8}{*}{ In. } & $4(2.6-8.5)$ & $<<0$ & 1 \\
\hline & & & $\mathrm{S} 2$ & & - & - & - \\
\hline & & & S3 & & $22(1.1-47.6)$ & $0.29(0-1.08)$ & 2 \\
\hline & & M. & S1 & & $4(2.6-8.5)$ & $<<0$ & 1 \\
\hline & & & S1 & & $4(0.4-7.5)$ & $<<0$ & 1 \\
\hline & \multirow{3}{*}{ B.B. } & F. & $\mathrm{S} 2$ & & - & - & - \\
\hline & & & S3 & & $50(14.6-85.3)$ & $1.08(0.75-2.87)$ & $1.5(1-7)$ \\
\hline & & F. & S1 & & $9(1.8-17.9)$ & $0.07(0.04-0.15)$ & 1 \\
\hline \multirow{8}{*}{ Contracaecum sp. } & \multirow{5}{*}{ S.R.C. } & & S1 & \multirow{8}{*}{ My. } & $6(1-12)$ & $<<0$ & 1 \\
\hline & & F. & $\mathrm{S} 2$ & & - & - & - \\
\hline & & & $\mathrm{S} 3$ & & $22(1.1-47.6)$ & $0.14(0-0.54)$ & 1 \\
\hline & & M. & S1 & & $2.7(0.6-7.1)$ & $<<0$ & 1 \\
\hline & & & S1 & & $29(19.4-38.7)$ & $0.44(0.25-0.64)$ & $1.72(1-2)$ \\
\hline & \multirow{3}{*}{ B.B. } & F. & S2 & & $45(25.4-65.7)$ & $0.51(0.13-0.89)$ & 1 \\
\hline & & & S3 & & $83(47.8-99.5)$ & $2.75(0-5)$ & $2.75(1-10)$ \\
\hline & & M. & $\mathrm{S} 1$ & & $4(0.8-8.3)$ & $<<0$ & 1 \\
\hline \multicolumn{8}{|l|}{ COPEPODA } \\
\hline \multirow{8}{*}{$\begin{array}{l}\text { Ergasilus sieboldii } \\
\text { Nordmann, } 1832\end{array}$} & \multirow{5}{*}{ S.R.C. } & & S1 & \multirow{8}{*}{ G. } & $8(2-14.4)$ & $0.07(0-0.16)$ & 1 \\
\hline & & F. & S2 & & $17(0.7-36.8)$ & $0.3(0-0.97)$ & 3 \\
\hline & & & S3 & & - & - & - \\
\hline & & M. & S1 & & $6(1.9-10.7)$ & $0.05(0-0.09)$ & 1 \\
\hline & & & $\mathrm{S} 1$ & & - & - & - \\
\hline & \multirow{3}{*}{ B.B. } & F. & $\mathrm{S} 2$ & & - & - & - \\
\hline & & & S3 & & - & - & - \\
\hline & & M. & S1 & & - & - & - \\
\hline \multirow{8}{*}{$\begin{array}{l}\text { Lernaea cyprinacea } \\
\text { Linnaeus, } 1758\end{array}$} & \multirow{5}{*}{ S.R.C. } & & S1 & \multirow{8}{*}{ S. } & - & - & - \\
\hline & & F. & $\mathrm{S} 2$ & & $25(4-48)$ & $0.2(0-0.51)$ & 1 \\
\hline & & & S3 & & - & - & - \\
\hline & & M. & $\mathrm{S} 1$ & & $5(1.4-9.8)$ & $<<0$ & 1 \\
\hline & & & $\mathrm{S} 1$ & & $7(1.4-14.1)$ & $0.06(0-0.12)$ & 1 \\
\hline & \multirow{3}{*}{ B.B. } & F. & $\mathrm{S} 2$ & & $13(0.5-41)$ & $<<0$ & 1 \\
\hline & & & S3 & & - & - & - \\
\hline & & M. & S1 & & $4(0.8-7.9)$ & $0.04(0-0.08)$ & $2(1-5)$ \\
\hline
\end{tabular}

A. (P.) felippei; in the mesentery were met. P. macrostomum and Contracaecum sp.; in the intestine was the acanthocephalan $W$. matercula; in the musculature was the met. A. (P.) angeloi; in the skin was the monogenean Gyrodactylus sp. and in the eye was the met. Thylodephylus sp.

The infracommunity and component community indexes are provided in Tab. IV. The comparison between samples sites showed higher Shannon-Wiener diversity index and Pielou evenness index in the females S1, S2 and males from S.R.C. against B.B.; the females of $\mathrm{S} 3$ and the males from B.B. had higher number of parasitic species against S.R.C. The males of B.B., compared with the females of the same sample site, had higher Shannon and Pielou indexes.

The Shannon and Pielou indexes showed similar pattern when was compared the different sizes of females in the same sample site. The higher values correspond to the S2, then S1 and last the S3. The number of parasitic species was similar between S1-S2, and S1-S3, but higher in S3 compared with S2. 
Tab. III. Berger Parker indexes of the parasites according to the microhabitat and size of Jenynsia multidentata Jenyns, 1842, and simple site [A.B., aortic bulb; B.B., low Sauce River of Bahia Blanca; F., female; E., eye; G., gills; H.S., host sex; I., intestine; M, male; Mu., musculature; My., mesentery; S., skin; S.I., site of infection; S.R.C., Salado River Channel; S.S., sample site; T.L., total length; S1, size 1 (T.L.<45 mm); S2, size 2 (T.L. = 45-60 mm); S3, size 3 (T.L. > $60 \mathrm{~mm})$ ].

\begin{tabular}{|c|c|c|c|c|c|c|c|}
\hline & S.I. & H.S. & S.S. & $\mathrm{S} 1$ & $\mathrm{~S} 2$ & $\mathrm{~S} 3$ & Total \\
\hline \multirow{4}{*}{$\begin{array}{l}\text { Met. Ascocotyle (Phagicola) diminuta (Stunkard } \\
\text { \& Haviland, 1924) }\end{array}$} & \multirow{4}{*}{ G. } & \multirow{2}{*}{ F. } & S.R.C. & 18.56 & 7.09 & 7.00 & 7.94 \\
\hline & & & B.B. & 7.31 & 43.01 & 71.00 & 17.98 \\
\hline & & \multirow{2}{*}{ M. } & S.R.C. & 11.79 & & & \\
\hline & & & B.B. & 12.24 & & & \\
\hline \multirow{4}{*}{ Met. Echinostomidae gen. sp. indet. } & \multirow{4}{*}{ G. } & \multirow{2}{*}{ F. } & S.R.C. & 2.90 & 10.79 & 75.22 & 26.79 \\
\hline & & & B.B. & 35.96 & 13.17 & & 32.46 \\
\hline & & \multirow{2}{*}{ M. } & S.R.C. & 5.49 & & & \\
\hline & & & B.B. & 38.18 & & & \\
\hline \multirow{4}{*}{$\begin{array}{l}\text { Met. of Ascocotyle (Phagicola) felippei Travassos, } \\
1929\end{array}$} & \multirow{4}{*}{ A.B. } & \multirow{2}{*}{ F. } & S.R.C. & 1.68 & 3.70 & & 2.38 \\
\hline & & & B.B. & 9.03 & 1.88 & & 6.41 \\
\hline & & \multirow{2}{*}{ M. } & S.R.C. & 0.20 & & & \\
\hline & & & B.B. & 4.88 & & & \\
\hline \multirow{4}{*}{$\begin{array}{l}\text { Met. of Pygidiopsis macrostomum Travassos, } \\
1928\end{array}$} & \multirow{4}{*}{ Мy. } & \multirow{2}{*}{ F. } & S.R.C. & 4.79 & 8.94 & 3.91 & 5.95 \\
\hline & & & B.B. & 7.73 & 10.22 & & 7.99 \\
\hline & & \multirow{2}{*}{ M. } & S.R.C. & 12.41 & & & \\
\hline & & & B.B. & 5.47 & & & \\
\hline \multirow{4}{*}{ Contracaecum sp. } & \multirow{4}{*}{ My. } & \multirow{2}{*}{ F. } & S.R.C. & 0.63 & & 0.22 & 0.61 \\
\hline & & & B.B. & 5.96 & 15.75 & 11.46 & 8.53 \\
\hline & & \multirow{2}{*}{ M. } & S.R.C. & 0.39 & & & \\
\hline & & & B.B. & 6.32 & & & \\
\hline \multirow{4}{*}{$\begin{array}{l}\text { Wolffhugelia matercula Mañé-Garzón \& Dei-Cas, } \\
1974\end{array}$} & \multirow{4}{*}{ I. } & \multirow{2}{*}{ F. } & S.R.C. & 3.01 & 0.93 & & 1.19 \\
\hline & & & B.B. & 2.65 & 0.27 & & 1.86 \\
\hline & & \multirow{2}{*}{ M. } & S.R.C. & 1.21 & & & \\
\hline & & & B.B. & 1.20 & & & \\
\hline \multirow{4}{*}{$\begin{array}{l}\text { Met. Ascocotyle (Phagicola) angeloi Travassos, } \\
1928\end{array}$} & \multirow{4}{*}{$\mathrm{Mu}$. } & \multirow{2}{*}{ F. } & S.R.C. & 0.21 & & & 0.16 \\
\hline & & & B.B. & 12.50 & & & 8.73 \\
\hline & & & S.R.C. & 0.40 & & & \\
\hline & & IVI. & B.B. & 4.75 & & & \\
\hline & & $\mathrm{F}$ & S.R.C. & 15.12 & 5.56 & & 4.15 \\
\hline Gurodactulus sn & $\mathrm{S}$ & T. & B.B. & 0.63 & 0.54 & & 0.50 \\
\hline yrowe lyius sp. & S. & $M$ & S.R.C. & 1.84 & & & \\
\hline & & IVI. & B.B. & 0.54 & & & \\
\hline & & & S.R.C. & & & & \\
\hline Met Thulodenh & $\mathrm{F}$ & $\Gamma$. & B.B. & 0.03 & 1.08 & & \\
\hline 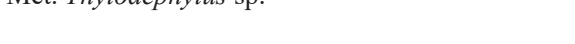 & 5. & $\mathrm{M}$ & S.R.C. & 3.67 & & & \\
\hline & & IVI. & B.B. & & & & \\
\hline
\end{tabular}

\section{DISCUSSION}

The great number of parasitic larval stages found in the examined fishes, and the high dominance observed in, mainly, all the microhabitats, seem to indicate that it possible that this fish is used as the food item for others vertebrates species (mainly birds) were the adult stage of those parasites could be found. As result of this, the one-side livebearers could be a link in the flow of energy inside the food chain, and its parasites used as biological tags .
The high prevalence, mean abundance and intensity of parasites in B.B. are the consequence of a rise the rate meeting between parasite and host due the size of water body (B.B. is smaller than S.R.C.). Also, exist the question "The chemical contaminants and environmental impacts of both sites are similar?". Even though this issue was not addressed in this paper, SCHENONE et al. (2007) found several contaminants in the Lower Salado River (S.R.C), like Cr, Pb, $\mathrm{Cu}$, and $\mathrm{Zn}$; but in Sauce Chico (B.B.), Rosso et al. (2011) found low anthropogenic contamination. According with 
Tab. IV. The infracommunity indexes [number of parasitic species (S), number of parasite (N), and the component community index Shannon-Wiener index of biodiversity (Shannon) and Equitability index of Pielou] calculated with Bayesian statistics according to the simple site, host sex and size. The mean are followed by the credibility range in parenthesis [B.B., low Sauce River of Bahia Blanca; F., females; M., males; S.R.C., Salado River Channel; T.L., total length; S1, size 1 (T.L. $<45 \mathrm{~mm}$ ); S2, size 2 (T.L. = 45-60 mm); S3, size 3 (T.L. $>60 \mathrm{~mm}$ ). In parenthesis are the $95 \%$ credibility limits.

\begin{tabular}{|c|c|c|c|c|c|c|}
\hline & & & \multicolumn{2}{|c|}{ Infracommunity indexes } & \multicolumn{2}{|c|}{ Component Community indexes } \\
\hline & & & $\mathrm{S}$ & $\mathrm{N}$ & Shannon & Pielou \\
\hline \multirow{6}{*}{ S.R.C. } & \multirow{4}{*}{ F. } & $\mathrm{S} 1$ & $2.99(2.38-3.6)$ & $7(5-9)$ & $1.69(1.49-1.88)$ & $0.61(0.54-0.68)$ \\
\hline & & $\mathrm{S} 2$ & $3.7(0-11)$ & $14(1-60)$ & $2.24(2.07-2.42)$ & $0.81(0.74-0.87)$ \\
\hline & & $\mathrm{S} 3$ & $2.17(1.44-2.9)$ & $32.86(1-85)$ & $0.88(0.59-1.16)$ & $0.32(0.21-0.42)$ \\
\hline & & $\mathrm{S} 1$ & $2.17(1.44-2.9)$ & $8(5-12)$ & $1.93(1.83-2.03)$ & $0.7(0.66-0.73)$ \\
\hline & \multirow[t]{2}{*}{ M. } & $\mathrm{S} 2$ & - & - & - & - \\
\hline & & $\mathrm{S} 3$ & - & - & - & - \\
\hline \multirow{6}{*}{ B.B. } & \multirow{4}{*}{$\mathrm{F}$} & $\mathrm{S} 1$ & $2.47(1.21-3.73)$ & $11(6-15)$ & $1.31(1.26-1.37)$ & $0.47(0.45-0.5)$ \\
\hline & & $\mathrm{S} 2$ & $1.38(0.43-2.34)$ & $3(1-6)$ & $1.92(1.79-2.04)$ & $0.69(0.65-0.74)$ \\
\hline & & $\mathrm{S} 3$ & $3.5(3-4)$ & $7(5-10)$ & $1.03(0.86-1.21)$ & $0.37(0.31-0.44)$ \\
\hline & & $\mathrm{S} 1$ & $3.5(3-4)$ & $7(5-9)$ & $1.49(1.43-1.56)$ & $0.54(0.52-0.56)$ \\
\hline & \multirow[t]{2}{*}{ M. } & $\mathrm{S} 2$ & - & - & - & - \\
\hline & & $\mathrm{S} 3$ & - & - & - & - \\
\hline
\end{tabular}

these records could be assumed that high prevalences and mean abundances of parasite in B.B. could be relationed with the less contaminant concentration in the environment or a combination of factors. The differences observed between sites in the P., M.A., and I. in the S3 could be a consequence a little number of host revised, only seven in S.R.C. and four in B.B.

Lecithasther confusus parasiziting J. multidentata is a new host and locality records. The Hemiuridae and Thylodelphys metacercariae (inside the vitreous humor), Glossocercus sp., nematode L4 (intestine) and de E. sieboldii are all new host records. The presence of $L$. confusus, metacercariae Hemiuridae g. sp. and E. sieboldii could be explained by the alternation of saline and freshwater in the S.R.C. allowing the development of a wide range of host organisms. Samples sites are connected with the respective estuaries and the fishes could go to more-saline waters, despite this, the sample site on Sauce Chico is far from the mouth of the channel, but in the S.R.C. fish were collected near to the Bahia Samborombón. The number of parasite species in each site (regardless size or gender of the host) is greater in S.R.C. (16 vs. 13 species) this could be, also, for the daily flow of salt water from the bay while in the Sauce Chico River freshwater predominates. The larvae nematode (L4) was not found in the S2 of both environments. Perhaps, the nematode found in host of S1 and S3 are different species and used different foods items as host. According to QUINTANS et al. (2009), there is a change in the alimentary items of this fishes according to the size. Jenynsia multidentata change when grow up, the zooplankton for the periphyton items and (when to be available) insects and crustaceans. That change in the prey items is a consequence of the mouth ontogeny (Guma'A, 1978; Mills et al., 1985; Lazzaro, 1987).

The differences observed between males and females could be as a result to differences in the alimentation or parasite susceptibility.

Digenean metacercariae are the most diverse and dominant species in J. multidentata of both sites, showing that in the environment live the intermediate hosts necessary to accomplish the life cycle of the parasites.

The difference in the Shannon-Wiener diversity index and Pielou equitability index observed between female sizes in both sites have a similar pattern: higher in S2, then S1 and last $\mathrm{S} 3$. The $\mathrm{S} 2$ represent fish of two years old, the infective parasite larva had more time to find the host and with that an increase on the equitability among the parasite species is observed. Also, the high microhabitats available in the $J$. multidentata make very low the competition between species. In S1 the fish are young so, they have a little time of exposure to be infected with many species and when the infection is accomplished the number of parasites that success is low. The S3 represent older fish and represent the survivors of S2. These fishes have a little diversity of parasites with high abundance, that reduces the Shannon and Pielou index. The specimens of S2 with more parasites died before reach the S3, this could be proved because the number of host of this size are very low.

When analyzes the community indexes between sites is evident a high Pielou equitability index from S.R.C. These could be, as we expose, due to an alternation of saline and freshwater in the S.R.C. that allows a high diversity of species and making none more dominant.

This is the first approximation to an analysis of the parasitic ecology on Jenynsia multidentata. The parasite fauna of this host could report important information and should be analyzed as indicator of biodiversity, food chain and contamination. Also, could be used the population of a parasite specie as an environment sentinel. On the other hands, some of this parasite could represents a risk for human health like the metacercariae Pygidiopsis sp. with reports parasitizing humans (CHAI \& LEE, 2002).

Acknowledgements. The authors thanks to Nicolas Bonel and Pilar Alda for the sampling effort in Bahía Blanca and Samborombon Bay also to Paula Marcotegui for her suggestions and helping in the collect of fishes. 


\section{REFERENCES}

Betito, R. 2006 Comparação da complexidade das adaptações bioecológicas de dois peixes (Jenynsia multidentata e Poecilia vivipara) (Cyprinodontiformes) no estuário da Lagoa dos Patos (RS, Brasil). Revista Didática Sistémica 3:71-100.

Bush, A. O.; Lafferty, K. D.; Lutz, J. L. \& Shostak, A.W. 1997. Parasitology meets ecology on its own terms: Margolis et al. revisited. Journal of Parasitology 83:575-583.

ChaI, J. Y. \& LeE S. H. 2002. Food-borne intestinal trematode infections in the Republic of Korea. Parasitology International 51:129-154.

EsCaLANTE, A. H. 1987. Alimentación de Bryconamericus iheringi y Jenynsia lineata lineata (Osteichthyes) en Sierra de la Ventana (Argentina). Anales del Museo de Historia Natural de Valparaíso 18:101-108.

Golicher, D. J.; O’Hara, R.B.; Ruiz Montoya, L. \& Cayuela, L. 2006. Lifting a veil on diversity: a Bayesian approach to fitting relativeabunance models. Ecological Applications 16(1):202-212.

Guma'A, S. A. 1978. The food and feeding habits of young perch, Perca fluviatilis, in Windermere. Freshwater Biology 8:177-187.

Iglesias, C.; Mazzeo, N.; Goyenola, G.; Fosalba, C.; Teixeira de Mello, F.; Garcia, S. \& Jeppesen, E. 2008. Field and experimental evidence of the effect of Jenynsia multidentata, a small omnivorousplanktivorous fish, on the size distribution of zooplankton in subtropical lakes. Freshwater Biology 53:1797-1807.

Lopez Cazorla, A.; Sidorkewicu, N. S. \& Forte, S. 2003. Edad y Crecimiento de Jenynsia lineata en la Cuenca alta del Río Sauce Grande, Provincia de Buenos Aires. Biologia Acuatica 20:68-72.

LuNASCHI, L. I. \& DraGo, F. B. 1995. Wolffughelia matercula Mañé-Garzón \& Dei-Cas, 1974 (Neoechinorhynchidae-Gracilisentinae) en peces de la provincia de Buenos Aires, Argentina. Gayana 59:109-115.

Lazzaro, X. 1987. A Review of Planktivorous Fishes: Their Evolution, Feeding, Behaviours, Selectivities and Impacts. Hydrobiologia 146:96167.

Magurran, A. E. 1988. Ecological diversity and its measurements. Princeton, Pricenton University Press. 179p.

Marti, G. A.; Azpeliculta, M. M.; Tranchida, M. C.; Pelizza, S. A. \& García, J. J. 2006. Predation efficiency of indigenous larvivorous fish species on Culex pipiens L. larvae (Diptera: Culicidae) in drainage ditches in Argentina. Journal of Vector Ecology 31:102-106.

Menni, R.; Gomez, S. E. \& Lopez Armengol, F. 1996. Subtle relationships: freshwater fishes and water chemistry in southern South America. Hydrobiologia 328:173-197.

Mills, C. A.; Behaumont, W. R. C. \& Clarke, R. T. 1985. Sources of variation in the feeding of larval dace Leucicus leuciscus in an english river. Transactions of the American Fisheries Society 114:519-524.

Moreno, O.; Granado, C. \& García Novo, F. 1986. Variabilidad morfológica de Lernaea cyprinacea (Crustacea, Copepoda) en el embalse de Arrocampo (cuenca del Tajo, Cáceres). Limnética 2:265270.

OstrowsKi DE NUÑEz, M. 1974. Estudio sobre estadios larvales de Trematodes Digeneos de peces Cyprinodontiformes. Physis, Seccion B 33:45-61
Ostrowski de Nuñez, M. 1976. Fauna de agua dulce en la República Argentina. IV. Las cercarias de Ascocotyle (A.) tenuicollis Price 1935 y de Pygidiopsis pindoramensis Travassos 1929 (Trematoda, Heterophyidae). Physis Seccion B 35:51-57.

Ostrowski De NuÑEz, M. 1992. Life history studies of Herophyid Trematodes in the Neogropical Region: Ascocotyle (Leighia) hadra sp. n. Memorias del Instituto Oswaldo Cruz 87:539-543.

OStrowsKi DE NUÑEZ, M. 1993. Life history studies of heterophyid trematodes in the Neotropical Region: Ascocotyle (Phagicola) diminuta (Stunkard \& Haviland, 1924) and A. (P.) angrense Travassos, 1916. Systematic Parasitology 24:191-199.

Ostrowski de NuÑez, M. 1998. Life cycle of Ascocotyle (Phagicola) angeloi (Digenea: Heterophyidae) in the Neotropical Region. Folia Parasitologica 45:1999-204.

OstrowSKI DE NUÑEZ, M. 2001. Life cycles of two next sibling species of Ascocotyle (Ascocotyle) (Digenea, Heterophyidae) in the Neotropical Region. Acta Parasitologica 46:119-129.

Pritchard, M. H. \& Kruse, G. O. W. 1982. The collection and preservation of animal parasites. Lincoln, University of Nebraska Press. 141p.

Quintans, F.; Scasso, F.; Loureiro, M. \& Yafe, A. 2009. Diet of Cnesterodon decemmaculatus (Poeciliidae) and Jenynsia multidentata (Anablepidae) in a hypertrophic shallow lake of Uruguay. Iheringia, Série Zoologia 99(1):99-105.

Ringuelet, R. A. 1975. Zoogeografía y ecología de los peces de aguas continentales de la Argentina y consideraciones sobre las áreas ictiológicas de América del Sur. Ecosur 2:1-122.

Ringuelet, R. A.; Aramburu, R. H. \& De Aramburu, A. A. 1967. Los peces argentinos de agua dulce. La Plata, Comisión de Investigación Científica Provincia de Buenos Aires (CIC). 602p

Romero, M. A. 2005. Estudio Preliminar de la parasito fauna de Jenynsia lineata (Jenyns, 1842) (Pisces: Atheriniformes) en cuerpos de agua dulce del área de Bahía Banca. Bahía Blanca, Universidad Nacional del Sur, Departamento de Biologia, Bioquimica y Farmacia. 48p.

Rosso, J. J.; Troncoso, J. J. \& Fernandez Cirelli, A. 2011. Geographic Distribution of Arsenic and Trace Metals in Lotic Ecosystems of the Pampa Plain, Argentina. Bulletin of Environmental Contamation and Toxicology 86:129-132.

Schenone, N.; Volpedo, A.V. \& Fernández Cirelli, A. 2007. Trace metal contents in water and sediments in Samborombón Bay wetland, Argentina. Wetland Ecology and Management 15:303-310.

SicCARDI, E. M. 1940. La viviparidad de Jenynsia lineata (Jenyns) Berg. Revista del Museo Argentino de Ciencias Naturales, Publicación Extra 121:1-8.

SzIDAT, L. 1969. Structure, development, and behaviour of new strigeatoid metacercariae from subtropical fishes of south America. Journal of the Fisheries Research Board of Canada 26:753-786.

Valdes, M. E.; Huerta, B.; Wunderlin, D. A.; Bistoni, M. A.; Barcelo, D. \& RoDRIGUEZ-MOZAZ, S. 2016. Bioaccumulation and bioconcetration of carbamazepine and other pharmaceuticals in fish under field and controlled laboratory experiments. Evidences of carbamazepine metabolization by fish. Science of The Total Environment 557558:58-67. 